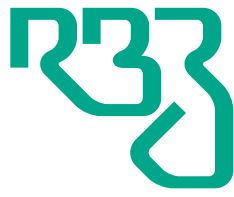

Brasileira de Zootecnia

Brazilian Journal of Animal Science ISSN 1806-9290 www.rbz.org.br

\section{Fermentation characteristics and in vitro ruminal digestion of yacon residue silage with lactic acid bacteria inoculant or beet pulp}

\author{
Lichao Wang $^{1}$ (D), Lihui Guan ${ }^{2}$ (iD), Jiachen Fang ${ }^{3}$ (DD, Yimin Cai ${ }^{4}$ (D), Yang \\ $\mathrm{Cao}^{{ }^{*}}$ (iD) \\ ${ }^{1}$ Heilongjiang Bayi Agricultural University, College of Animal Science and Veterinary \\ Medicine, Daqing, China. \\ ${ }^{2}$ Hebei North University, Department of Animal Science, Zhangjiakou, China. \\ ${ }^{3}$ Hirosaki University, Faculty of Agriculture and Life Science, Hirosaki, Japan. \\ ${ }^{4}$ National Institute of Livestock and Grassland Science, Tsukuba, Japan.
}

\begin{abstract}
In this study, we examined the effects of lactic acid bacteria (LAB) inoculant and beet pulp (BP) on the quality of yacon (Smallanthus sonchifolius) residue silage. Yacon silage was prepared using a small-scale system of silage fermentation, and the treatments were as follows: control silage without any additive and silages with LAB inoculant Chikuso-1 (Lactobacillus plantarum, $5 \mathrm{mg} / \mathrm{kg}$, fresh matter basis), BP (30\% fresh matter basis), and LAB+BP. Silages were opened on days 3, 5, 7, 15, 30, and 60 of fermentation. The chemical composition, organic acid content, and in vitro ruminal digestion of the 60-day silage were determined. The $\mathrm{pH}$ of LAB-treated silage was lower than that of the silage without LAB. Furthermore, the LAB-treated silage presented the lowest ammonia-N concentration among the four types of silages, and it inhibited the growth of harmful bacteria including molds and clostridia during the early stages of fermentation. The BP-treated silage had lower contents of crude protein and ether extract than the silage without BP. The 60-day silage inoculated with LAB had the highest in vitro dry matter (DM) digestibility among the four silages, and the production of methane was lower than that of the silage treated with BP. The $\mathrm{pH}$ showed a tendency toward stabilization after 30 days of fermentation, although the concentration of lactic acid exhibited fluctuations during fermentation. The results suggest that the addition of $\mathrm{LAB}$ and $\mathrm{BP}$ can improve the fermentation quality of yacon silage, and the yacon silage with LAB might increase in vitro DM digestibility, but decrease in vitro ruminal methane production.
\end{abstract}

Keywords: dry matter digestibility, microorganism, silage, volatile fatty acids, yacon

\title{
Introduction
}

Yacon (Smallanthus sonchifolius; family Asteraceae) (Koike et al., 2010) is a tropical high-mountain plant native to the Andes in South America. During recent years, yacon has been successfully cultivated in Japan and China (mainly in Yunnan, Fujian, Hainan, Guizhou, Hunan, Hubei, Shandong, Henan, and Hebei Provinces) (Hao and Zhang, 2011). Tissue culture techniques have also been employed in Heilongjiang and Jilin Provinces for cultivating yacon (Liu et al., 2009a). Yacon is a highly productive crop, producing up to $100 \mathrm{t} \mathrm{ha}^{-1}$ of tuberous roots (Grau and Rea, 1997; Silva et al., 2002). Morphologically, yacon resembles a sweet potato; its roots are crisp, juicy, and sweet, with a refreshing taste (Hermann et al., 1999). The plant is rich in oligofructans, amino acids, and vitamins; and especially the content of oligosaccharides in yacon tuber is relatively high (Liu et al., 2009b). 
Usually, only yacon tuber is consumed by humans; its leaves and stems are robust, especially the stems up to $2 \mathrm{~m}$ height (Graefe et al., 2004). Yacon leaves and stems are agricultural wastes and are rarely used. When treated inappropriately, these wastes can cause serious environment pollution - waste of resources. Yacon tubers do not contain starch (Hermann et al., 1999). The storage carbohydrates include sucrose, fructose, and glucose (Graefe et al., 2004). Koike et al. (2009) proposed that the entire yacon plant can be used as animal feed owing to its antioxidative activity.

Thus, yacon wastes (including leaves, stems, and yacon fruit residues) can be used as a high-quality feed material. The fermentation quality of yacon silage can be improved with the use of lactic acid bacteria (LAB) or dried beet pulp (BP). Lactic acid bacteria are beneficial for silage fermentation as they inhibit the growth of harmful bacteria (Cao et al., 2011). The content of soluble sugars in BP is high, and they act as a substrate of fermentation for LAB (Ni et al., 2017). Additionally, with dried BP, the moisture content of silage can be adjusted. Moreover, as yacon has a sweet and refreshing taste, the palatability of yacon silage can be improved (Chavez and Huntington, 2013).

The objective of this study was to determine the fermentation characteristics and microbial composition obtained with different treatments of yacon residue silage and assess the in vitro rumen digestibility of yacon residue silages.

\section{Material and Methods}

Yacon residues were collected from a farm in Tsukuba, Japan (longitude $139.737566^{\circ} \mathrm{E}$, latitude $35.681825^{\circ} \mathrm{N}$, elevation $46 \mathrm{~m}$ ) during November 2015. Yacon plants were cultivated as reported previously (Koike et al., 2009). Animal study was conducted according to the guidelines set by the institutional committee on animal use.

Yacon silage was prepared using BP [dry matter (DM), 90.7\%; organic matter (OM), 94.9\%; crude protein (CP), 8.4\%; ether extract (EE), 0.7\%; acid detergent fiber (ADF), 25.6\%; neutral detergent fiber (NDF), 52.1\%; water-soluble carbohydrates (WSC), 2.1\% of DM] or LAB (Lactobacillus plantarum Chikuso-1; Snow Brand Seed, Sapporo, Japan). Experimental treatments were as follows: control silage without any additive, silage with LAB $\left(5 \mathrm{mg} / \mathrm{kg}\right.$ fresh matter basis; number of LAB $=1.0 \times 10^{5} \mathrm{cfu} / \mathrm{g}$ of FM), silage with BP (200 $\mathrm{g} / \mathrm{kg}$ fresh matter basis), and LAB+BP.

A silage was prepared using a small-scale system of silage fermentation (Cai et al., 1998). Approximately $500 \mathrm{~g}$ of yacon residue, chopped to a length of approximately $20 \mathrm{~mm}$, was thoroughly mixed and packed in plastic bags (Hiryu KN type, $270 \times 400 \mathrm{~cm}$; Asahikasei, Tokyo, Japan). The bags were then sealed using a vacuum sealer (BH 950; Matsushita, Tokyo, Japan) and stored at $205^{\circ} \mathrm{C}$. Eighteen silo bags were used per treatment. Three silo bags per treatment were opened on days 3, 5, 7, 15, 30, and 60 . The samples were dried in a forced-air oven at $60^{\circ} \mathrm{C}$ for $48 \mathrm{~h}$ and then passed through a 1-mm screen with a Wiley mill (ZM200; Retch GmbH \& Co., KG, Haan, Germany) for the chemical analysis and in vitro digestibility measurements.

Two adult wethers, average initial body weight (BW) of $78.5 \mathrm{~kg}$ and fitted with rumen cannulas, were used as ruminal fluid donors. The wethers were fed a basal diet of $50 \%$ reed canary grass (Phalaris arundinacea L.) hay and 50\% commercial feed concentrate (Koushi-Ikusei-Special; Kitanihon Kumiai Feed Co. Ltd., Miyagi, Japan) at maintenance energy level (2.0\% DM of their BW); they had free access to clean drinking water and were fed once daily at $09.00 \mathrm{~h}$. The ruminal fluid was collected in plastic bottles via the rumen cannulas $2 \mathrm{~h}$ after feeding. The fluid was filtered through four layers of cheese cloth and combined (equal volumes of filtrate). The combined filtrate was mixed with $\mathrm{CO}_{2}$-bubbled McDougall's artificial saliva (pH 6.8; McDougall, 1948) at a ratio of 1:4 (v/v). Subsequently, $50 \mathrm{~mL}$ of buffered-rumen fluid was transferred to 128 -mL serum bottles containing $0.5 \mathrm{~g}$ of sample and flushed with $\mathrm{O}_{2}$-free $\mathrm{CO}_{2}$. The bottles were capped with a butyl rubber stopper and sealed with an aluminum cap. The bottles were then incubated at $39^{\circ} \mathrm{C}$ for $72 \mathrm{~h}$ (Mohammed et al., 2004) in a water bath with a reciprocal shaker (100 strokes/min). To terminate fermentation at the end of incubation, $25 \mu \mathrm{L}$ of formaldehyde solution $(35 \%)$ were injected into the serum bottles, which were immediately sealed and

R. Bras. Zootec., 48:e20180152, 2019 
cooled to room temperature. Gas samples were collected from the serum bottles using an air syringe and injected into a gas chromatograph (GC323; GL Sciences Inc. Tokyo, Japan) equipped with a thermal conductivity detector and a stainless-steel column (WG-100 SUS, $1.8 \mathrm{~m}$ length $\times 6.35 \mathrm{~mm}$ internal diameter); methane production in each serum bottle was measured. The analytical conditions were as follows: column oven temperature, $50^{\circ} \mathrm{C}$; injector temperature, $50^{\circ} \mathrm{C}$; and detector temperature, $50{ }^{\circ} \mathrm{C}$.

Separate subsamples of the supernatant were used to determine volatile fatty acids (VFA) and ammonia- $\mathrm{N}$ concentrations by the same methods followed for the silage filtrate. Finally, the contents in the bottles were passed through previously weighed filter papers, and the residue was washed with $50 \mathrm{~mL}$ of hot $\left(50^{\circ} \mathrm{C}\right)$ distilled water. The filter papers containing the residue were then oven-dried for $48 \mathrm{~h}$ at $60^{\circ} \mathrm{C}$, and the digestibility of the residual DM was determined (Mohammed et al., 2004; Cao et al., 2010a). The yacon residue and its silage were dried in a forced-draught oven at $60^{\circ} \mathrm{C}$ for $48 \mathrm{~h}$ and ground to powder of particle size 2-mm with a sample mill (Foss Tecator; Akutalstuku, Tokyo, Japan). The content of DM, CP, and EE was analyzed according to respective methods 934.01, 976.05, and 920.39 of AOAC (1990). The OM content was calculated as weight loss upon ashing. The ADF and NDF concentrations were analyzed according to the methods of Robertson and Van Soest (1981) and Van Soest et al. (1991), respectively. Heat-stable amylase and sodium sulfite were used to determine the NDF concentration; the results are expressed without residual ash. Concentration of non-fibrous carbohydrates (NFC) was calculated as follows: NFC $=100-\mathrm{CP}-\mathrm{NDF}-\mathrm{EE}-$ ash (NRC, 2001). Watersoluble carbohydrates were extracted by heating $0.5 \mathrm{~g}$ of tissue in $50 \mathrm{~mL}$ deionized water for $1 \mathrm{~h}$ in a $40{ }^{\circ} \mathrm{C}$ water bath. The extract, which was gently swirled once during 1 -h incubation, was vacuumfiltered through a double-layer glass fiber filter, and the content of WSC, including glucose, sucrose, and fructose, was determined by HPLC (Jasco Corp.) according to the method of Kagan et al. (2014). The analytical conditions were as follows: Shodex Sugar SC1011 column $(8.0 \mathrm{~mm}$ internal diameter $\times 30 \mathrm{~cm}$ length; Shoko, Tokyo, Japan); oven temperature, $80^{\circ} \mathrm{C}$; mobile phase, distilled water; and flow rate, $1.0 \mathrm{~mL} / \mathrm{min}$ (Jasco RI-1530; Jasco Corp.).

After filtration through a microporous membrane, the organic acid (including lactic acid and VFA) content of silage was determined using the filtrate. The $\mathrm{pH}$ of the filtrate was measured using a glass electrode pH meter (Horiba D-21; Horiba, Kyoto, Japan), and the ammonia-N concentration was determined by steam distillation of the filtrates (Cao et al., 2010b). The organic acid content was measured by HPLC (Jasco Corp., Tokyo, Japan) according to the method described by Cai et al. (1999a). The $\mathrm{pH}$, and VFA, and ammonia-N concentrations of the ruminal fluid samples were measured following the same methods employed for the silage filtrates.

Yacon residue or its silage sample $(20 \mathrm{~g})$ was blended with $180 \mathrm{~mL}$ sterilized water to obtain the filtrate. Equal quantity of filtrate from three bags of each treatment was mixed and serially diluted from $10^{-1}$ to $10^{-5}$ with sterilized water. By the plate count method, we determined the number of LAB on Lactobacilli de Man, Rogosa, and Sharpe (MRS) agar (Difco Laboratories, Detroit, MI, USA) incubated under anaerobic conditions (Anacrobic box; TEHER Hard Anaerobox, ANX-1; Hirosawa Ltd., Tokyo, Japan) at $30^{\circ} \mathrm{C}$ for $48 \mathrm{~h}$. Bacilli and aerobic bacteria were differentiated by the colony shape and counted on nutrient agar (Nissui Ltd., Tokyo, Japan); the aerobic bacteria were incubated under aerobic conditions at $30^{\circ} \mathrm{C}$ for $24 \mathrm{~h}$. The number of coliform bacteria was counted on blue light broth agar (Nissui Ltd., Tokyo, Japan) incubated at $30^{\circ} \mathrm{C}$ for $48 \mathrm{~h}$. Molds and yeasts were counted on potato dextrose agar (Nissui Ltd., Tokyo, Japan) incubated at $30^{\circ} \mathrm{C}$ for $24 \mathrm{~h}$. Yeasts were distinguished from molds or bacteria by colony appearance and cell morphology. The number of clostridia was determined on clostridia count agar (Nissui Ltd., Tokyo, Japan) incubated under anaerobic conditions at $30^{\circ} \mathrm{C}$ for $48 \mathrm{~h}$. Colonies were counted as a viable number of microorganisms (cfu/g of fresh matter).

The data on chemical composition, in vitro ruminal DM digestibility, methane production, and fermentation products after $6 \mathrm{~h}$ of incubation of silages opened on day 60 were analyzed by the oneway analysis of variance (ANOVA). Data of fermentative characteristics of silage opened on days 3 to 60 were analyzed with the GLM procedure of SAS software (Statistical Analysis System, version 9.2) according to the model for a completely randomized design with a $4 \times 6$ [additive treatment (AT) $\times$ ensiling days (ED)] design:

R. Bras. Zootec., 48:e20180152, 2019 


$$
\mathrm{Y}_{i j}=\mu+\alpha_{i}+\beta_{j}+(\alpha \times \beta)_{i j}+\mathrm{e}_{i j}
$$

in which $\mu=$ overall mean, $\alpha_{i}=$ additive treatment effect ( $i=$ control, $\left.\mathrm{LAB}, \mathrm{BP}, \mathrm{LAB}+\mathrm{BP}\right), \beta_{j}=$ effect of ensiling days $(j=3,5,7,15,30,60),(\alpha \times \beta)_{i j}=$ effect of interaction between additive treatment $i$ and ensiling days $j$, and $\mathrm{e}_{i j}=$ random error. Tukey's test was used to identify differences $(\mathrm{P}<0.05)$ between means.

\section{Results}

The content of OM in yacon was higher, but the content of EE was lower in yacon, compared with those in the stem, leaves, and residue of yacon (Table 1). The content of WSC was relatively high in the yacon stem. The $\mathrm{pH}$ of yacon roots, stems, and leaves was 6.34, 6.15, and 6.04, respectively. Furthermore, the number of LAB, bacilli, aerobic and coliform bacteria, molds and yeasts, and clostridia in yacon residues was $10^{3}, 10^{4}, 10^{8}, 10^{4}$, and $10^{3} \mathrm{cfu} / \mathrm{g}$ of FM, respectively.

There was no difference in the NDF concentration among the four silages at 60 days of fermentation (Table 2), but significant differences $(\mathrm{P}<0.05)$ were observed in $\mathrm{DM}, \mathrm{OM}, \mathrm{CP}, \mathrm{EE}, \mathrm{NFC}$, and ADF concentrations among the four silages. The DM level decreased in the following order: $\mathrm{LAB}+\mathrm{BP}>\mathrm{BP}$ $>\mathrm{LAB}>$ control silage. The content of $\mathrm{OM}$ in silages treated with $\mathrm{BP}$ was higher $(\mathrm{P}<0.05)$ than that in silages not treated with BP. The content of CP, EE, and ADF of silages without BP was significantly higher $(\mathrm{P}<0.05)$ than that of silages with $\mathrm{BP}$, and the content of $\mathrm{CP}$ and ADF of $\mathrm{LAB}+\mathrm{BP}$-treated silage was higher $(\mathrm{P}<0.05)$ than that of the BP-treated silage. Furthermore, the NFC concentration of silage with $\mathrm{BP}$ was higher $(\mathrm{P}<0.05)$ than that of silages without BP.

Additive treatment (AT), ensiling days (ED), and their interaction (AT $\times$ ED) influenced $\mathrm{pH}$ and the content of lactic acid, acetic acid, and ammonia-N (Table 3). The moisture content was affected not only by ED but also by AT $\times$ ED. The $\mathrm{pH}$ and acetic acid content of the silage treated with LAB were significantly lower $(\mathrm{P}<0.05)$ than those of the silage without LAB. The lactic acid content of silage treated with $\mathrm{LAB}$ was higher $(\mathrm{P}<0.05)$ than that of silage without $\mathrm{LAB}$. A comparison among the four types of silages revealed that the ammonia- $N$ concentration was the lowest $(\mathrm{P}<0.05)$ in LAB-treated silage, followed by the control, LAB+BP-treated, and BP-treated silages. Propionic and butyric acids

Table 1 - Chemical and microorganism composition and pH of yacon, stem, and leaf components of yacon plant

\begin{tabular}{|c|c|c|c|c|}
\hline & Yacon & Stem & Leaves & Residue of yacon \\
\hline \multicolumn{5}{|l|}{ Chemical composition } \\
\hline Dry matter (DM; g/kg) & 133 & 113 & 185 & 121 \\
\hline Organic matter (g/kg DM) & 930 & 876 & 862 & 854 \\
\hline Crude protein (g/kg DM) & 59 & 106 & 224 & 177 \\
\hline Ether extract (g/kg DM) & 6 & 10 & 30 & 17 \\
\hline Acid detergent fiber (g/kg DM) & 282 & 514 & 433 & 399 \\
\hline Neutral detergent fiber (g/kg DM) & 462 & 570 & 447 & 451 \\
\hline \multicolumn{5}{|l|}{ Water-soluble carbohydrates } \\
\hline Sucrose (g/kg DM) & 14 & 24 & 2 & 11 \\
\hline Glucose (g/kg DM) & 1 & 17 & 4 & 6 \\
\hline Fructose (g/kg DM) & 13 & 18 & 9 & 9 \\
\hline $\mathrm{pH}$ & 6.34 & 6.15 & 6.04 & 6.22 \\
\hline \multicolumn{5}{|c|}{ Microorganism composition (cfu/g fresh matter) } \\
\hline Lactic acid bacteria & $2.0 \times 10$ & $7 \times 10^{2}$ & $6 \times 10^{3}$ & $1.6 \times 10^{3}$ \\
\hline Bacilli bacteria & $2.5 \times 10^{4}$ & $5.0 \times 10^{3}$ & $1.8 \times 10^{4}$ & $2.1 \times 10^{4}$ \\
\hline Aerobic bacteria & $1.6 \times 10^{6}$ & $1.8 \times 10^{6}$ & $1.0 \times 10^{8}$ & $7.5 \times 10^{8}$ \\
\hline Coliform bacteria & $4.8 \times 10^{4}$ & $5.2 \times 10^{4}$ & $4.0 \times 10^{8}$ & $6.5 \times 10^{8}$ \\
\hline Molds & $3.2 \times 10^{3}$ & $4.5 \times 10^{3}$ & $1.3 \times 10^{4}$ & $1.1 \times 10^{4}$ \\
\hline Yeasts & $1.0 \times 10^{3}$ & $4.0 \times 10^{3}$ & $3.0 \times 10^{4}$ & $2.2 \times 10^{4}$ \\
\hline Clostridia & $5.0 \times 10^{2}$ & $4.0 \times 10^{2}$ & $1.0 \times 10^{3}$ & $9.5 \times 10^{3}$ \\
\hline
\end{tabular}


were not detected among the four types of silages. A comparison of the ensiling days showed that the $\mathrm{pH}$ of the silage during the later stages of fermentation was lower $(\mathrm{P}<0.05)$ than that during the early stages of fermentation. The lactic acid content of all silages tended to decrease with the storage time. The silage obtained on day 60 of fermentation had the lowest $(\mathrm{P}<0.05)$ acetic acid content compared with that on other ensiling days. The ammonia- $\mathrm{N}$ concentration in the silage decreased rapidly during the early stages of fermentation, whereas from days 7-15, there was a marginal increase in all the silages.

When ensiled for three days, the number of LAB, bacilli, aerobic bacteria, and coliform bacteria was $10^{8}-10^{9}, 10^{2}-10^{4}, 10^{8}-10^{9}$, and $10^{6}-10^{8} \mathrm{cfu} / \mathrm{g}$ of $\mathrm{FM}$, respectively, in the four types of silages (Table 4). However, except in the control and BP-treated silages, molds, yeasts, and clostridia were not detected in the other two silages; $10^{3} \mathrm{cfu} / \mathrm{g}$ of FM yeasts were found in the BP-treated silage on day 3 of fermentation. After three days of ensiling, $10^{6} \mathrm{cfu} / \mathrm{g}$ of FM molds and $10^{3} \mathrm{cfu} / \mathrm{g}$ of FM clostridia were found in the BP-treated silage, whereas $10^{2} \mathrm{cfu} / \mathrm{g}$ of FM molds and $10^{3} \mathrm{cfu} / \mathrm{g}$ of FM clostridia were found in the control silage, but yeasts were not detected. After five days of fermentation, the number of aerobic bacteria, coliform bacteria, and molds decreased in all silages. On days 15, 30, and 60 of fermentation, the number of $\mathrm{LAB}$ presented a decreasing trend with the increase in fermentation days.

Table 2 - Chemical composition of yacon residue silage after 60 days of storage

\begin{tabular}{lcccccc}
\hline & \multicolumn{4}{c}{ Treatment } & \multirow{2}{*}{ SEM } & P-value \\
\cline { 2 - 5 } & Control & LAB & BP & LAB+BP & & \\
\hline Dry matter (DM; g/kg) & $123 \mathrm{~d}$ & $126 \mathrm{c}$ & $372 \mathrm{~b}$ & $401 \mathrm{a}$ & 0.47 & $<0.0001$ \\
Organic matter (g/kg DM) & $865 \mathrm{~b}$ & $864 \mathrm{~b}$ & $911 \mathrm{a}$ & $910 \mathrm{a}$ & 2.91 & 0.0005 \\
Crude protein (g/kg DM) & $169 \mathrm{a}$ & $168 \mathrm{a}$ & $104 \mathrm{c}$ & $124 \mathrm{~b}$ & 0.40 & $<0.0001$ \\
Ether extract (g/kg DM) & $24 \mathrm{a}$ & $23 \mathrm{a}$ & $11 \mathrm{~b}$ & $16 \mathrm{~b}$ & 0.78 & 0.0008 \\
Non-fibrous carbohydrates (g/kg DM) & $86 \mathrm{~b}$ & $85 \mathrm{~b}$ & $176 \mathrm{a}$ & $159 \mathrm{a}$ & 8.72 & 0.0035 \\
Acid detergent fiber (g/kg DM) & $511 \mathrm{a}$ & $502 \mathrm{a}$ & $362 \mathrm{c}$ & $403 \mathrm{~b}$ & 6.70 & 0.0002 \\
Neutral detergent fiber (g/kg DM) & 587 & 587 & 619 & 611 & 6.70 & 0.0557 \\
\hline
\end{tabular}

LAB - lactic acid bacteria (Lactobacillus plantarum Chikuso-1); BP - beet pulp; SEM - standard error of the mean. ${ }^{1} \mathrm{NFC}=100-\mathrm{CP}-\mathrm{NDF}-\mathrm{EE}-$ ash

Means within a row with different letters differ $(\mathrm{P}<0.05)$.

Table 3 - Changes in pH and fermentation products of yacon residue silage ensiled for 3, 5, 7, 15, 30, and 60 days

\begin{tabular}{|c|c|c|c|c|c|}
\hline Treatment & $\begin{array}{c}\text { Moisture } \\
(\mathrm{g} / \mathrm{kg})\end{array}$ & $\mathrm{pH}$ & $\begin{array}{l}\text { Lactic acid } \\
\text { (g/kg of FM) }\end{array}$ & $\begin{array}{l}\text { Acetic acid } \\
\text { (g/kg of FM) }\end{array}$ & $\begin{array}{l}\text { Ammonia-N } \\
\text { (g/kg of FM) }\end{array}$ \\
\hline \multicolumn{6}{|l|}{ Additive treatment means } \\
\hline Control & $877 a$ & $4.76 \mathrm{a}$ & $14.1 \mathrm{~b}$ & $4.9 \mathrm{a}$ & $1.03 \mathrm{~b}$ \\
\hline LAB & $876 a$ & $4.06 \mathrm{~b}$ & $19.3 \mathrm{a}$ & $1.3 \mathrm{~b}$ & $0.79 \mathrm{c}$ \\
\hline $\mathrm{BP}$ & $628 \mathrm{~b}$ & $4.72 \mathrm{a}$ & $13.9 \mathrm{~b}$ & $5.9 \mathrm{a}$ & $1.44 \mathrm{a}$ \\
\hline $\mathrm{LAB}+\mathrm{BP}$ & $612 c$ & $4.15 b$ & $19.1 \mathrm{a}$ & $1.4 \mathrm{~b}$ & $1.31 \mathrm{ab}$ \\
\hline \multicolumn{6}{|l|}{ Means of ensiling days } \\
\hline 3 & 748 & $4.64 \mathrm{a}$ & $20.0 \mathrm{a}$ & $4.1 \mathrm{a}$ & $1.50 \mathrm{a}$ \\
\hline 5 & 754 & $4.69 \mathrm{a}$ & $17.8 \mathrm{a}$ & $3.5 \mathrm{a}$ & $0.89 \mathrm{~b}$ \\
\hline 7 & 755 & $4.76 \mathrm{a}$ & 17.0ab & $4.0 \mathrm{a}$ & $0.86 \mathrm{~b}$ \\
\hline 15 & 738 & $4.22 \mathrm{~b}$ & $14.5 \mathrm{bc}$ & $3.1 \mathrm{a}$ & $1.28 \mathrm{ab}$ \\
\hline 30 & 749 & $4.11 \mathrm{~b}$ & $12.4 \mathrm{a}$ & $3.8 \mathrm{a}$ & $1.14 \mathrm{ab}$ \\
\hline 60 & 745 & $4.11 \mathrm{~b}$ & $12.0 \mathrm{c}$ & $1.7 \mathrm{~b}$ & 1.18ab \\
\hline SEM & 2.9 & 0.041 & 0.46 & 0.20 & 0.07 \\
\hline \multicolumn{6}{|c|}{ Significance of main effects and interactions } \\
\hline Additive treatment (AT) & $<0.0001$ & $<0.0001$ & $<0.0001$ & $<0.0001$ & $<0.0001$ \\
\hline Ensiling days (ED) & 0.1098 & $<0.0001$ & $<0.0001$ & $<0.0001$ & 0.0043 \\
\hline $\mathrm{AT} \times \mathrm{ED}$ & 0.5336 & 0.0039 & 0.0383 & 0.0011 & 0.0275 \\
\hline
\end{tabular}

BP - beet pulp; FM - fresh matter; LAB - lactic acid bacteria (Lactobacillus plantarum, Chikuso-1); SEM - standard error of the mean. Means within column with different letters differ $(\mathrm{P}<0.05)$. 
During the early stages of ensiling, the number of coliform bacteria decreased rapidly, and they were not detected in all the silages on days 15, 30, and 60 of fermentation. Molds, yeasts, and clostridia were not detected in all silages after five days of fermentation.

Dry matter digestibility of LAB silage was the highest $(\mathrm{P}<0.05)$ among the four silages, followed by the control, BP-treated, and LAB+BP-treated silages (Table 5). The production of methane in the silage without BP was lower than that in the silage with $\mathrm{BP}(\mathrm{P}<0.05)$. Furthermore, compared with that in the control silage, the production of methane in the LAB silage was reduced by $22.4 \%$. The total VFA concentration in the control silage was the lowest $(\mathrm{P}<0.05)$ among the four silages. The content of acetic acid, n-butyric acid, and I-caproic acid, and the acetic acid:propionic acid ratio (A:P) did not differ significantly among the four silages. The production of acetic acid among the LAB-treated silage was similar to that of the control or BP-treated silage, but lower than that of the $\mathrm{LAB}+\mathrm{BP}$-treated silage. Moreover, the production of acetic acid in the silage with BP was higher $(\mathrm{P}<0.05)$ than that in the control silage. The production of $n$-valeric acid in the control silage was similar to that in the LAB-treated silage, but higher $(\mathrm{P}<0.05)$ than that in the BP-and BP + LABtreated silages.

The addition of BP (containing high WSC) or LAB to silage can improve the fermentation quality, decrease some fermentation loss, and influence the ruminal digestion characteristics of the silage. However, the effects of added LAB are influenced by the silage materials, that is, LAB can produce sufficient lactic acid to decrease $\mathrm{pH}$, inhibit the growth of harmful bacteria, and decrease some fermentation loss, resulting in silage of good quality. Adding LAB and BP can make the silage quality good and produce lactic acid and propionic acid quickly.

Table 4 - Change in counts of viable microorganisms (cfu/g FM) of yacon residue silage ensiled for 3, 5, 7, 15, 30, and 60 days

\begin{tabular}{|c|c|c|c|c|c|c|c|c|}
\hline & $\begin{array}{c}\text { Ensiling } \\
\text { days }\end{array}$ & LAB & $\begin{array}{c}\text { Bacilli } \\
\text { bacteria }\end{array}$ & $\begin{array}{l}\text { Aerobic } \\
\text { bacteria }\end{array}$ & $\begin{array}{l}\text { Coliform } \\
\text { bacteria }\end{array}$ & Molds & Yeasts & Clostridia \\
\hline \multirow[t]{6}{*}{ Control } & 3 & $3.6 \times 10^{8}$ & $1.8 \times 10^{4}$ & $2.8 \times 10^{8}$ & $8.5 \times 10^{7}$ & $5.0 \times 10^{2}$ & ND & $1.0 \times 10^{3}$ \\
\hline & 5 & $1.7 \times 10^{8}$ & $3.5 \times 10^{3}$ & $6.5 \times 10^{7}$ & $7.5 \times 10^{5}$ & ND & ND & ND \\
\hline & 7 & $2.7 \times 10^{8}$ & $1.7 \times 10^{4}$ & $2.8 \times 10^{6}$ & $9.9 \times 10^{4}$ & ND & ND & ND \\
\hline & 15 & $2.0 \times 10^{8}$ & $1.3 \times 10^{4}$ & $2.2 \times 10^{4}$ & ND & ND & ND & ND \\
\hline & 30 & $1.8 \times 10^{8}$ & $3.6 \times 10^{4}$ & $3.7 \times 10^{4}$ & ND & ND & ND & ND \\
\hline & 60 & $1.9 \times 10^{8}$ & $5.0 \times 10^{3}$ & ND & ND & ND & ND & ND \\
\hline \multirow[t]{6}{*}{ LAB } & 3 & $1.1 \times 10^{9}$ & $2.2 \times 10^{4}$ & $1.2 \times 10^{9}$ & $4.3 \times 10^{6}$ & ND & ND & ND \\
\hline & 5 & $1.1 \times 10^{9}$ & $3.0 \times 10^{4}$ & $2.3 \times 10^{4}$ & ND & ND & ND & ND \\
\hline & 7 & $7.1 \times 10^{8}$ & $3.4 \times 10^{4}$ & $7.0 \times 10^{5}$ & ND & ND & ND & ND \\
\hline & 15 & $7.7 \times 10^{8}$ & $5.5 \times 10^{3}$ & $1.4 \times 10^{4}$ & ND & ND & ND & ND \\
\hline & 30 & $3.4 \times 10^{8}$ & $2.4 \times 10^{4}$ & $3.7 \times 10^{4}$ & ND & ND & ND & ND \\
\hline & 60 & $3.0 \times 10^{8}$ & $1.4 \times 10^{5}$ & ND & ND & ND & ND & ND \\
\hline \multirow[t]{6}{*}{ BP } & 3 & $8.4 \times 10^{8}$ & $9.0 \times 10^{3}$ & $3.3 \times 10^{8}$ & $1.5 \times 10^{8}$ & $2.0 \times 10^{6}$ & $1.1 \times 10^{3}$ & $1.0 \times 10^{3}$ \\
\hline & 5 & $1.9 \times 10^{8}$ & $3.0 \times 10^{4}$ & $4.0 \times 10^{6}$ & $3.8 \times 10^{6}$ & ND & ND & ND \\
\hline & 7 & $4.7 \times 10^{8}$ & $3.1 \times 10^{4}$ & $5.7 \times 10^{6}$ & $2.6 \times 10^{6}$ & ND & ND & ND \\
\hline & 15 & $5.4 \times 10^{8}$ & $1.7 \times 10^{4}$ & $1.4 \times 10^{4}$ & ND & ND & ND & ND \\
\hline & 30 & $4.8 \times 10^{8}$ & $2.0 \times 10^{4}$ & $2.7 \times 10^{4}$ & ND & ND & ND & ND \\
\hline & 60 & $2.3 \times 10^{8}$ & $1.0 \times 10^{4}$ & $2.9 \times 10^{4}$ & ND & ND & ND & ND \\
\hline \multirow[t]{6}{*}{$\mathrm{LAB}+\mathrm{BP}$} & 3 & $9.2 \times 10^{8}$ & $8.5 \times 10^{2}$ & $1.2 \times 10^{9}$ & $5.4 \times 10^{6}$ & ND & ND & ND \\
\hline & 5 & $9.6 \times 10^{8}$ & $2.1 \times 10^{4}$ & $3.4 \times 10^{4}$ & $3.6 \times 10^{4}$ & ND & ND & ND \\
\hline & 7 & $2.0 \times 10^{9}$ & $2.9 \times 10^{4}$ & $7.0 \times 10^{5}$ & $1.7 \times 10^{4}$ & ND & ND & ND \\
\hline & 15 & $1.2 \times 10^{9}$ & $1.3 \times 10^{4}$ & $2.8 \times 10^{4}$ & ND & ND & ND & ND \\
\hline & 30 & $8.3 \times 10^{8}$ & $1.1 \times 10^{4}$ & $1.6 \times 10^{4}$ & ND & ND & ND & ND \\
\hline & 60 & $4.9 \times 10^{6}$ & $6.0 \times 10^{5}$ & ND & ND & ND & ND & ND \\
\hline
\end{tabular}

BP - beet pulp; FM - fresh matter; LAB - lactic acid bacteria (Lactobacillus plantarum Chikuso-1); ND - not detected. 
Table 5 - Measurements of DM digestibility, methane production, and VFA concentration of in vitro incubation with rumen fluid of yacon residue silage after 60 days of storage

\begin{tabular}{|c|c|c|c|c|c|c|}
\hline \multirow{2}{*}{ Item } & \multicolumn{4}{|c|}{ Treatment } & \multirow{2}{*}{ SEM } & \multirow{2}{*}{ P-value } \\
\hline & Control & LAB & $\mathrm{BP}$ & $\mathrm{LAB}+\mathrm{BP}$ & & \\
\hline DM digestibility (\%) & $54.1 \mathrm{~b}$ & $58.6 a$ & $48.9 c$ & $48.4 \mathrm{c}$ & 0.567 & $<0.0001$ \\
\hline $\mathrm{CH}_{4}\left(\mathrm{~L} \mathrm{~kg}^{-1} \mathrm{DDM}\right)$ & $19.6 b$ & $15.2 b$ & $31.7 a$ & $31.2 \mathrm{a}$ & 1.238 & $<0.0001$ \\
\hline Total VFA (mM) & $0.56 \mathrm{~b}$ & $0.62 \mathrm{a}$ & $0.60 \mathrm{a}$ & $0.60 \mathrm{a}$ & 0.008 & 0.0040 \\
\hline Acetic acid (mol \%) & $37.6 \mathrm{c}$ & $39.2 \mathrm{bc}$ & 39.9ab & $41.5 \mathrm{a}$ & 0.479 & 0.0030 \\
\hline Propionic acid (mol \%) & 33.3 & 34.1 & 35.0 & 33.6 & 0.691 & 0.3789 \\
\hline n-butyric acid (mol \%) & 22.2 & 20.7 & 21.4 & 20.9 & 1.311 & 0.8502 \\
\hline n-valeric acid (mol \%) & $6.5 a$ & $5.7 \mathrm{ab}$ & $3.6 \mathrm{bc}$ & $3.0 \mathrm{c}$ & 0.534 & 0.0050 \\
\hline I-caproic acid (mol \%) & 0.2 & 0.1 & 0.5 & 0.6 & 0.107 & 0.0520 \\
\hline$A: P$ & 1.1 & 1.1 & 1.1 & 1.2 & 0.022 & 0.1454 \\
\hline
\end{tabular}

A:P - acetic acid to propionic acid ratio; BP - beet pulp; DDM - digestible dry matter; DM - dry matter; LAB - lactic acid bacteria (Lactobacillus plantarum Chikuso-1); SEM - standard error of the mean; VFA - volatile fatty acid.

Means within a column with different letters differ $(\mathrm{P}<0.05)$.

\section{Discussion}

The fermentation quality of the LAB and BP groups was significantly better than that of the control group. In the LAB treatment group, silage $\mathrm{pH}$ decreased rapidly, inhibiting the growth of harmful bacteria and increasing the quality of fermentation. The BP treatment increases soluble sugar and fermentation substrate, regulates water, and makes fermentation more complete. Groups LAB+BP and $\mathrm{BP}$ have higher DM, OM, and NFC compared with the control group. In the LAB, BP, and LAB+BP groups, the number of lactic acid bacteria was significantly higher than that in control group.

The yacon residue has higher moisture, CP, and WSC content, but lower OM and NDF content than those of fresh forages such as timothy grass, orchard grass, and perennial ryegrass (Cai et al., 1999b; $\mathrm{Xu}$ et al., 2007). Hermann et al. (1999) reported that yacon roots are a poor source of protein (2.7$4.9 \mathrm{~g} / \mathrm{kg}$ of FM). Further, yacon leaves have higher CP and EE content than those in yacon stems and roots (Liu et al., 2009b).

The present in vitro study was conducted to determine the ruminal fermentative characteristics of four types of yacon silages and the effects of addition of LAB and BP on the ruminal digestive characteristic of these silages on day 60 of ensiling. It is well established that LAB play an important role in silage fermentation. The function of LAB inoculants is to ensure rapid and efficient fermentation of WSC into lactic acid (Weinberg et al., 1993). Furthermore, the LAB level is a significant factor in predicting the adequacy of silage fermentation and in determining whether to add bacterial inoculants to silage materials. Generally, when the LAB level reaches $10^{5}$ (cfu/g of FM), silage can be well preserved (Cai et al., 1999b; Cao et al., 2011). However, the LAB level was $10^{3}$ and the aerobic bacteria level was $>10^{8}$ in yacon residues (Table 1), suggesting that certain inoculants are necessary for high-quality silage fermentation. The inoculant strain used in the present study was L. plantarum Chikuso-1, which promotes lactic acid fermentation, and it can grow well in low-pH environments. Therefore, silage prepared using this strain can promote the propagation of $\mathrm{LAB}$, decrease $\mathrm{pH}$, inhibit the growth of clostridia and aerobic bacteria, and improve the quality of silage (Cai et al., 1999b; Cao et al., 2011). The factors affecting fermentation quality include not only the physiological properties of epiphytic bacteria but also the chemical composition of the silage material (Cai et al., 1999b; Cao et al., 2011). Lactic acid bacteria can increase the content of lactic acid in silage (Cai, 2001; Cai et al., 2003), and they are commonly used in the preparation of silage (Cao et al., 2010a).

Beet pulp is rich in highly soluble carbohydrates. A previous study (Cao et al., 2011) reported its successful use in silage fermentation. In the present study, the addition of BP did not increase the lactic acid content significantly; however, the addition of LAB or BP + LAB increased the lactic acid content significantly. This might be because LAB converted more fermentable sugars to lactic acid (Cai, 2001; 
Cai et al., 2003; Cao et al., 2010a). One of the major advantages of inoculants that contain lactic acid bacteria is their ability to increase the efficiency and rate of lactic acid production, thereby, reducing proteolysis in silo (Davies et al., 1998). The epiphytic LAB convert WSC into organic acids during the ensiling process; thus, decreasing the $\mathrm{pH}$, which inhibits the growth of some microorganisms, such as bacilli, coliform bacteria, aerobic bacteria, yeasts, and molds, eventually inhibits the degradation of proteins (Cao et al., 2011). In the present study, the CP content of LAB-treated silage reduced marginally compared with that of the control silage. The fermentation of silage tended to be rapid and vigorous with the faster accumulation of lactic acid (Table 3), which inhibited the production of ammonia- $\mathrm{N}$ during the early stages of ensiling. However, the lactic acid content in silage decreased with storage time, except that on day 30 of fermentation. These observations are in agreement with the findings of a previous study (Kobayashi et al., 2010). Cao et al. (2011) reported that the $\mathrm{pH}$ of silage decreased rapidly after three days of ensiling. However, in the present study, an apparent decrease in $\mathrm{pH}$ was observed from day 15 of ensiling until day 60.

Stokes (1992) reported that the addition of LAB to silage can improve the DM content in the silage. In the present study, the LAB-, BP-, and LAB+BP-treated silages had higher DM content than that of the control silage on day 60 . These results are in agreement with the findings of our previous studies (Cai et al., 1998, 1999b; Cai, 1999). Furthermore, the moisture content in silage material is also a major factor influencing silage fermentation (Garcia et al., 1989). An intrinsic characteristic of yacon residue is its very high moisture content, and this is a major limitation to its use as livestock feed (Cao et al., 2011). In the present study, considering our preliminary experiment results, we added dried BP to the yacon and adjusted the water to $60 \%$.

After $72 \mathrm{~h}$ of incubation in vitro, all yacon residue silages had high DM digestibility (48.4-58.6\%), which is similar to that of some vegetable residue silages incubated in vitro, such as white, Chinese, and red cabbage and lettuce silages (Cao et al., 2011). The in vitro DM digestibility of silage with LAB was higher than that of silage without LAB, because LAB reduces DM loss during silage fermentation (Cai, 2001; Cai et al., 2003). In the present study, the LAB silage presented increased DM digestibility compared with that of the control silage, but the BP-treated silage presented decreased DM digestibility.

According to the chemical composition (Table 2) and fermentation quality (Table 3), the CP in BPtreated silages was degraded to produce ammonia- $\mathrm{N}$, resulting in nutrient loss during the ensiling processes, possibly decreasing DM digestibility of BP-treated silages. The LAB-treated silage decreased the production of methane in the rumen liquid by $22.4 \%$ compared with that of the control silage. This might be because the addition of LAB increased the lactic acid content in the silage. When silage containing a high lactic acid content is incubated in vitro, either lactic acid or pyruvic acid is converted to propionic acid (Leng, 1970; Cao et al., 2010a). At the same time, lactic acid is utilized in the rumen by lactate-utilizing bacteria such as Megasphaera elsdenii, Selenomonas ruminantium, and Veillonella parvula, and propionate is generally produced (Dawson et al., 1997; Russell and Wallace, 1997), which can reduce methanogenesis, because electrons are used during propionate formation (Asanuma and Hino, 2002; Cao et al., 2012). If hydrogen is used to convert lactic acid to propionic acid (Moss et al., 2000), hydrogen availability decreases, which in turn inhibits the conversion of hydrogen and $\mathrm{CO}_{2}$ to methane. Therefore, we suspect that the higher lactic acid content in the LAB silage might have led to the production of propionic acid, consequently lowering methane production. In addition, a large amount of lactic acid may cause changes in microorganisms, such as nisin. Streptococcus mutans can inhibit methane production (Shen et al., 2016). The specific reasons still need to be further studied.

Some studies (Fahey and Berger, 1988; Cao et al., 2010b, 2012) have also reported that silage with high DM digestibility and lactic acid content can decrease methane production in the rumen. Cao et al. (2012) reported that total mixed ration silage with high DM digestibility can contribute to high ruminal total VFA production. In the present study, higher DM digestibility of LAB silage might have led to the production of VFA. However, we were unable to elucidate why LAB+BP-treated silage had the lowest production of $n$-valeric acid. Cao et al. (2011) reported that the LAB inoculants increased not only DM digestibility after in vitro incubation but also decreased ruminal methane production, which is consistent with the results of the present study. The LAB inoculants improved the fermentation 
quality of yacon silages, which could decrease the degradation of $\mathrm{CP}$ in the yacon silage. The addition of BP to yacon silage reduced DM digestibility and n-valeric acid production after in vitro incubation and increased the total VFA and even methane production. We could not elucidate the underlying mechanism. Further studies are needed to elucidate the probiotic effects of adding LAB or BP to yacon residue silage in ruminants. In BP-treated silage, because BP have larger buffer ability, the resulting lactic acid is neutralized, and the $\mathrm{pH}$ is higher than in control or LAB-treated silage. At this time, the growth of beneficial bacteria is poor, the microbial activity is strong, and the protein is decomposed, resulting in high ammonia- $\mathrm{N}$ content.

Furthermore, in the present study, the interaction between AT and ED influenced not only the pH and organic acid content but also the ammonia- $\mathrm{N}$ concentration. We propose that, as described in a previous study (Cai et al., 1999b; Cao et al., 2011), the factors involved in fermentation quality include chemical composition, particularly the WSC content in the silage material, and the physiological properties of epiphytic bacteria. The silage is completely fermented during the early stages of ensiling; LAB can produce a sufficient amount of lactic acid to decrease $\mathrm{pH}$, inhibit the growth of harmful bacteria, and decrease some fermentation loss, resulting in silage of high quality (Cao et al., 2011).

However, the effects of inoculated LAB are influenced by the number of ensiling days. When the yacon residue contains a high WSC content during silage fermentation, LAB can produce a sufficient amount of lactic acid to decrease the $\mathrm{pH}$, thus inhibiting the growth of harmful bacteria and decreasing some fermentation loss, which results in the production of good quality silage. With increase in the number of ensiling days, the lactic acid produced can be consumed or decomposed by some microbes. Therefore, the concentration of lactic acid during the later stages was lower than that during the earlier stage in the present study, which is consistent with the findings of a previous study (Kobayashi et al., 2010); however, we could not elucidate the underlying mechanism.

\section{Conclusions}

Yacon residues have a high nutritive value and potential as a good protein source for ruminants. Yacon silage with lactic acid bacteria can improve fermentation quality and in vitro dry matter digestibility and effectively reduce in vitro methane production.

\section{Conflict of Interest}

The authors declare no conflict of interest.

\section{Author Contributions}

Conceptualization: Y. Cao. Data curation: L. Wang and J. Fang. Formal analysis: L. Wang. Investigation: L. Guan. Project administration: Y. Cai and Y. Cao. Visualization: Y. Cao. Writing-original draft: L. Wang. Writing-review \& editing: J. Fang, Y. Cai and Y. Cao.

\section{Acknowledgments}

This study was supported by grants from the Heilongjiang Bayi Agricultural University Support Program for San Heng San Zong (No. TDJH201805), the National Key R\&D Program of China (2018YFD0502100), Project of Central Guide Local Science and Technology Development (No. ZY16A06), and the National Natural Science Foundation of China (No. 31772673).

\section{References}

AOAC - Association of Official Analytical Chemistry. 1990. Official methods of analysis. 15th ed. AOAC International, Arlington, VA. 
Asanuma, N. and Hino, T. 2002. Regulation of fermentation in a ruminal bacterium, Streptococcus bovis, with special reference to rumen acidosis. Animal Science Journal 73:313-325. https://doi.org/10.1046/j.1344-3941.2002.00044.x

Cai, Y. 1999. Identification and characterization of Enterococcus species isolated from forage crops and their influence on silage fermentation. Journal of Dairy Science 82:2466-2471. https://doi.org/10.3168/jds.S0022-0302(99)75498-6

Cai, Y. 2001. The role of lactic acid bacteria in the preparation of high fermentation quality. Grassland Science 47:527-533. (In Japanese with English abstract.)

Cai, Y.; Benno, Y.; Ogawa, M.; Ohmomo, S.; Kumai, S. and Nakase, T. 1998. Influence of Lactobacillus spp. from an inoculant and of Weissella and Leuconostoc spp. from forage crops on silage fermentation. Applied and Environmental Microbiology 64:2982-2987.

Cai, Y.; Benno, Y.; Ogawa, M. and Kumai, S. 1999b. Effect of applying lactic acid bacteria isolated from forage crops on fermentation characteristics and aerobic deterioration of silage. Journal of Dairy Science 82:520-526. https://doi org/10.3168/jds.S0022-0302(99)75263-X

Cai, Y.; Fujita, Y.; Murai, M.; Ogawa, M.; Yoshida, N.; Kitamura, R. and Miura, T. 2003. Application of lactic acid bacteria (Lactobacillus plantarum Chikuso-1) for silage preparation of forage paddy rice. Grassland Science 49:477-485.

Cai, Y.; Kumai, S.; Ogawa, M.; Benno, Y. and Nakase, T. 1999a. Characterization and identification of Pediococcus species isolated from forage crops and their application for silage preparation. Applied and Environmental Microbiology 65:2901-2906.

Cao, Y.; Cai, Y.; Takahashi, T.; Yoshida, N.; Tohno, M.; Uegaki, R.; Nonaka, K. and Terada, F. 2011. Effect of lactic acid bacteria inoculant and beet pulp addition on fermentation characteristics and in vitro ruminal digestion of vegetable residue silage. Journal of Dairy Science 94:3902-3912. https://doi.org/10.3168/jds.2010-3623

Cao, Y.; Takahashi, T.; Horiguchi, K. and Yoshida, N. 2010a. Effect of adding lactic acid bacteria and molasses on fermentation quality and in vitro ruminal digestion of total mixed ration silage prepared with whole crop rice. Grassland Science 56:19-25. https://doi.org/10.1111/j.1744-697X.2009.00168.x

Cao, Y.; Takahashi, T.; Horiguchi, K.; Yoshida, N. and Cai, Y. 2010b. Methane emissions from sheep fed fermented or nonfermented total mixed ration containing whole-crop rice and rice bran. Animal Feed Science and Technology 157:72-78. https://doi.org/10.1016/j.anifeedsci.2010.02.004

Cao, Y.; Takahashi, T.; Horiguchi, K.; Yoshida, N. and Zhou, D. 2012. In vitro ruminal dry matter digestibility and methane production of fermented total mixed ration containing whole-crop rice and rice bran. Grassland Science 58:133-139. https://doi.org/10.1111/j.1744-697X.2012.00254.X

Chavez, S. J. and Huntington, G. B. 2013. Intake in cattle of a ground switchgrass and alfalfa hay mixture blended with various levels of sucrose or citric acid. Animal Feed Science and Technology 184:33-37. https://doi.org/10.1016/j. anifeedsci.2013.05.015

Davies, D. R.; Merry, R. J.; Williams, A. P.; Bakewell, E. L.; Leemans, D. K. and Tweed, J. K. S. 1998. Proteolysis during ensilage of forages varying in soluble sugar content. Journal of Dairy Science 81:444-453. https://doi.org/10.3168/jds.S00220302(98)75596-1

Dawson, K. A.; Rasmussen, M. A. and Allison, M. J. 1997. Digestive disorgers and nutritional toxicity. p.633-660. In: The rumen microbial ecosystem. 2nd ed. Hobson, P. N. and Stewart, C. S., eds. Blackie Academic and Professional, London.

Fahey, G. C. and Berger, L. L. 1988. Carbohydrate nutrition in ruminants. p.269-297. In: The ruminant animal: Digestive physiology and nutrition. Church, D. C., ed. Prentice Hall, Englewood Cliffs, New Jersey.

Garcia, A. D.; Olson, W. G.; Otterby, D. E.; Linn, J. G. and Hansen, W. P. 1989. Effects of temperature, moisture, and aeration on fermentation of alfalfa silage. Journal of Dairy Science 72:93-103. https://doi.org/10.3168/jds.S0022-0302(89)79084-6

Graefe, S.; Hermann, M.; Manrique, I.; Golombek, S. and Buerkert, A. 2004. Effects of post-harvest treatments on the carbohydrate composition of yacon roots in the Peruvian Andes. Field Cops Research 86:157-165. https://doi. org/10.1016/j.fcr.2003.08.003

Grau, A. and Rea, J. 1997. Yacon (Smallanthus sonchifolius [Poepp. \& Endl.] H. Robinson). p.199-242. In: Andean roots and tubers: Ahipa, Arracacha, Maca and Yacon. Hermann, M. and Heller, J., eds. IPGRI, Rome.

Hao, Y. and Zhang, M. 2011. Cultivation situation and prospect of yacon industry in China. Journal of Shanxi Agricultural Science 39:383-388. (In Chinese.)

Hermann, M.; Freire, I. and Pazos, C. 1999. Compositional diversity of the yacon storage root. p.425-432. In: Impact on a changing world. Program Report 1997-1998. CIP, Lima, Peru.

Kagan, I. A.; Kirch, B. H.; Thatcher, C. D.; Teutsch, C. D. and Pleasant, R. S. 2014. Chromatographic profiles of nonstructural carbohydrates contributing to the colorimetrically determined fructan, ethanol-soluble, and water-soluble carbohydrate contents offive grasses. Animal Feed Science and Technology 188:53-63. https://doi.org/10.1016/j. anifeedsci.2013.10.017

Kobayashi, H.; Cai, Y. and Uegaki, R. 2010. Microorganism composition of high moisture Italian ryegrass (Lolium multiflorum Lam.) and its fermentation characteristics of silage inoculated with lactic acid bacteria. Grassland Science 56:39-46.

R. Bras. Zootec., 48:e20180152, 2019 
Koike, A.; Murata, T.; Matsuda, Y.; Masuoka, C.; Okamoto, C. and Kabata, K. 2009. Cultivation and ensilage of yacon plants [Smallanthus sonchifolius (Poepp. \& Endl.) H. Robinson] and the function of yacon silage. Grassland Science 55:6-10. https://doi.org/10.1111/j.1744-697X.2009.00130.x

Koike, A.; Pradhan, R.; Murata, T.; Yasuda, S.; Igoshi, K.; Okamoto, C. and Kabata, K. 2010. Effect of yacon silage on feed digestibility, blood characteristics and amount of urinary 8-hydroxydeoxyguanosine in ewes. Grassland Science 56:95-100. https://doi.org/10.1111/j.1744-697X.2010.00180.x

Leng, R. A. 1970. Formation and production of volatile fatty acids in the rumen. p.406-421. In: Physiology of digestion and metabolism in the ruminant. Phillipson, A. T., ed. Oriel Press, Newcastle upon Tyne, England.

Liu, J.; Li, J.; Lan, H.; Yang, Y. and Zheng, M. 2009b. Analysis of the nutritional composition in different plant parts of yacon. Acta Prataculturae Sinica 18:236-240. (In Chinese.)

Liu, D.; Shen, J.; Li, H. and Cong, H. 2009a. Tissue culture of yacon. Journal of Jiamusi Univerisity (Nat SciEdn) 27:306-311. (In Chinese.)

McDougall, E. I. 1948. Studies on ruminant saliva. 1. The composition and output of sheep's saliva. Biochemical Journal 43:99-109. https://doi.org/10.1042/bj0430099

Mohammed, N.; Ajisaka, N.; Lila, Z. A.; Hara, K.; Mikuni, K.; Hara, K.; Kanda, S. and Itabashi, H. 2004. Effect of Japanese horseradish oil on methane production and ruminal fermentation in vitro and in steers. Journal of Animal Science 82:1839-1846. https://doi.org/10.2527/2004.8261839x

Moss, A. R.; Jouany, J. P. and Newbold, J. 2000. Methane production by ruminants: its contribution to global warming Ann Zootech 49:231-253. https://doi.org/10.1051/animres:2000119

Ni, K. K.; Wang, F. F.; Zhu, B. G.; Yang, J. X.; Zhou, G. A.; Pan, Y.; Tao, Y. and Zhong, J. 2017. Effects of lactic acid bacteria and molasses additives on the microbial community and fermentation quality of soybean silage. Bioresource Technology 238:706-715. https://doi.org/10.1016/j.biortech.2017.04.055

NRC - National Research Council. 2001. Nutrient requirements of dairy cattle. 7th rev. ed. National Academy Press, Washington, DC

Robertson, J. B. and Van Soest, P. J. 1981. The detergent system of analysis and its application to human foods. p.123-158. In: The analysis of dietary fiber in food. James, W. P. and Theander, O., eds. Marcel Dekker, New York.

Russell, J. B. and Wallace, R. J. 1997. Energy-yielding and energy-consuming reactions. p.246-282. In: The rumen microbial ecosystem. 2nd ed. Hobson, P. N. and Stewart, C. S., eds. Blackie Academic and Professional, London.

Shen, S.; Liu, Z.; Chen, Y.; Lv, P. and Zhu, W. 2016. Effects of nisin on in vitro fermentation, methanogenesis and functional microbial populations of the rumen. Acta Microbiologica Sinica 56:1348-1357.

Silva, M. A. S.; Hidalgo, A. F.; Morais, L. A. S.; Gonçalves, M. A. and Silva, S. M. P. 2002. Production of yacon plantlet (Polymnia sonchifolia Poep. et Endl.) in different organic fertilization. Acta Horticulturae 576:285-287. https://doi.org/10.17660/ ActaHortic.2002.576.42

Stokes, M. R. 1992. Effects of an enzyme mixture, an inoculant, and their interaction on silage fermentation and dairy production. Journal of Dairy Science 75:764-773. https://doi.org/10.3168/jds.S0022-0302(92)77814-X

Van Soest, P. J.; Robertson, J. B. and Lewis, B. A. 1991. Methods for dietary fiber, neutral detergent fiber, and nonstarch polysaccharides in relation to animal nutrition. Journal of Dairy Science 74:3583-3597. https://doi.org/10.3168/jds. S0022-0302(91)78551-2

Weinberg, Z. G.; Ashbell, G.; Hen, Y. and Azrieli, A. 1993. The effect of applying lactic acid bacteria at ensiling on the aerobic stability of silages. Journal of Applied Bacteriology 75:512-518. https://doi.org/10.1111/j.1365-2672.1993.tb01588.x

Xu, C. C.; Cai, Y.; Zhang, J. G. and Ogawa, M. 2007. Fermentation quality and nutritive value of a total mixed ration silage containing coffee grounds at ten or twenty percent of dry matter. Journal of Animal Science 85:1024-1029. https://doi.org/10.2527/jas.2005-628 